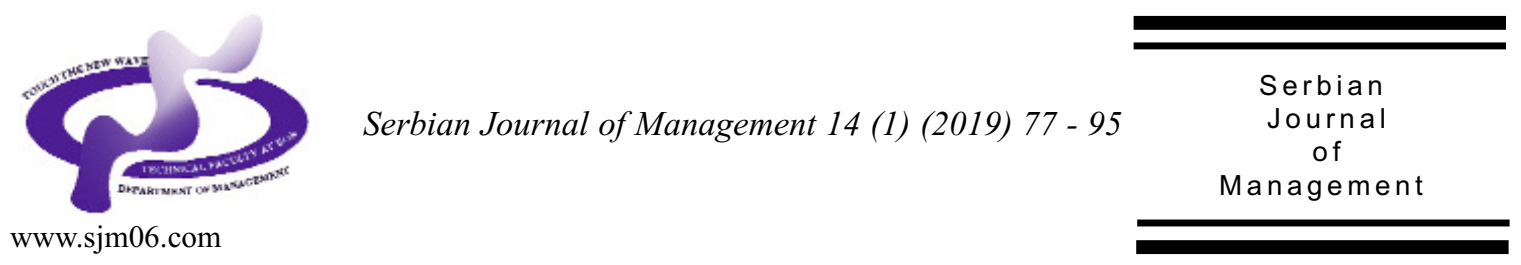

\title{
EXPLORING ANTECEDENTS OF RESPONSIBLE CONSUMPTION USING STRUCTURAL EQUATION MODELING
}

\author{
Vijay Kumar Jain ${ }^{*}$, Pankaj Chamolab

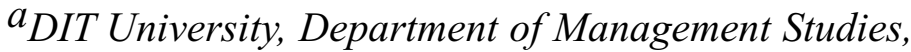 \\ Dehradun, Uttarakhand 248001, India

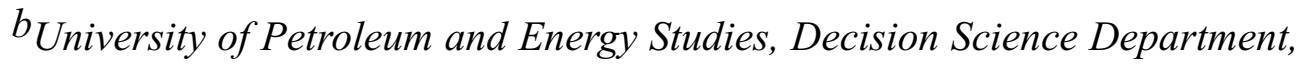 \\ Dehradun, Uttarakhand 248007, India
}

(Received 01 March 2018; accepted 08 August 2018)

\begin{abstract}
The perennial use of resources due to excess consumption has endangered the environment and is a grave concern for all of us. The current rate of resource consumption may deprive the future generation from the resources that we have been enjoying. The conservation of these resources for long requires judicious and rational consumption practices from consumers. Therefore, responsible consumption is need of hour to further prevent environmental degradation and resources depletion. This paper aims to explore the antecedents of responsible consumption. A theoretical model was developed to explain and empirically verify the antecedents of responsible consumption. Four antecedents namely environmental education, perception of fair trade, taxation and neuroticism have been taken as exogenous variables. The model was tested and statistically validated using structural equation modeling relying on data collected through 300 respondents. The environmental education has emerged as the most important antecedent of responsible consumption followed by taxation, perception of fair trade and neuroticism respectively. The finding of the study would contribute towards enhancing responsible and judicious use of resources, thereby, reducing consumption and improving environment.
\end{abstract}

Keywords: consumption, fair trade, resources, responsibility

\section{INTRODUCTION}

The availability of natural resources is the only reason for existence of living being on the earth. However, the incessant consumption of these resources is causing irreparable damage to the environment and is grave concern for all of us. The burgeoning

\footnotetext{
* Corresponding author: vijayjain22@gmail.com
}

DOI: $10.5937 /$ sjm14-16715 
population and exponential growth of countries like India, China and Brazil are driving demand for products and are creating burden on already exhausted resources. The humans now require 50\% more natural resources than 30 years ago, at around 60 billion tons of raw materials in a year (Sustainable Europe Research Institute, 2000). This rise in resources extraction is not only threating environment but also causing social problems in the form of human rights violation and poor working conditions. Further, the rapid exploitation of natural resources have already costed us very high in the form of change in climate, declining fresh water and forest reserves, extinction of many species and soil erosion (Human Development Report, 1998). The future generation will not be able to enjoy the resources that the present generation is enjoying if the perennial use resources continue with the same pace. The consumption of people in rich countries are ten times higher than those in developing countries. Mass consumption and consumerism have become the lifestyle of social classes. The unrivalled growth of population in developing countries and growing population in India will further require products thereby pushing demand. This in turn will create solid waste and carbon emission, thus creating harm to the environment. Hence, worsening environment and rapid depletion of resources requires necessity for new consumption practices and put question mark on the assumption that consumers are rational decision makers.

In recent years, responsible consumption issue has got attention from academicians, environmentalist and intellectuals because of growing concern about the unintended consequences of overconsumption among consumers (Gonzalez et al., 2009). The growing importance of responsible consumption can be assessed from the fact that it is now figures among the seventeen goals that form 2030 agenda for the United Nations sustainable development goals (United Nations, 2016). Every purchase made by consumers have environmental and social impacts so little change in consumers' consumption practices may bring big impact on society and environment. Therefore, this put direct onus on consumers to be more responsible for their consumption and require them to be more rational in choices of goods to preserve the environment. The conservation of resources is only possible when consumers consume responsibly. In the light of incessant extraction and overconsumption of resources, the current study makes an attempt to conceptualize responsible consumption. Further, it identifies the antecedents that lead to responsible consumption. Understanding of responsible consumption antecedents would help in encouraging it.

\section{LITERATURE REVIEW AND HYPOTHESES DEVELOPMENT}

Consumption has been defined as an activity which involves apparently endless pursuit of wants and insatiability (Campbell, 1987). Consumers may have different motives for indulging in consumption. Conventionally, the obsession for instant gratification has been seen one reason for careless spending on consumption. The hedonism and pleasure are two important forces for consumption among consumers who are more oriented towards enjoyment rather than caring about the future (Miles, 2000). The growing income and affluence is 
one of the reasons behind overconsumption. Consumption is seen as symbol of social status, prestige and social acceptance. Consumers not only purchase goods to fulfill their basic needs but also to fill some voids in life and reflect their status, thereby, leading to irresponsible consumption which could have avoided and saved some resources. Therefore, the traditional view of consumption must be reconsidered in response to overconsumption and consumers must embrace responsible consumption as a philosophy of their consumption habits.

The concept of responsible consumption was first coined in social movements and international aid and solidarity associationsfair trade in 1960. The term responsible consumption is the outcome of grassroots social movement that was initiated as a protest movement and alternatives culture (Wagner, 1960). Formally, it was first defined as efficient and rational use of resources (Fisk, 1973). Consumption is defined as responsible when consumers takes into account the impact of consumption on the quality of human life in all the respect including health, natural resources management, economy fight against poverty alleviation, social exclusion etc. Apart from this, knowing "how much is enough "is also important for consumers to behave responsibly.

Responsible consumption is conscious and judicious use of resources which aims to improve the quality of life without causing environmental degradation and compromising the need of coming generation. It is about making well informed choices and being aware of own spending habits and choosing environmental friendly and ethical purchase. In the light of above literature, we conceptualize the new definition of "responsible consumption as consumption practices that are rational and consider social, ethical and environmental impact of purchase and contribute towards bridging social disparity of resources existing among people". That means rationality, social justice and resource efficiency are the essence of responsible consumption. It will put a moral and ethical bar on consumption above which the consumption tends to be waste that could have been saved and distributed to others especially the impoverished. Table 1 present the brief summary of past researches conducted with respect to variables taken for the current study.

\subsection{Perception of Fair Trade and Responsible Consumption}

Fair trade is regulatory system that sets and imposes social and environmental standards on production globally (Raynolds, 2012). It is an emerging initiative which attempts to socially regulate the market especially in food sector. This new governance mechanism is also known as private standards. Although, many provisions have been put in place in the form of certifications, codes and guidelines governing global production system, fair trade connects labor, community and environmental concerns especially in food items. With the advancement of global market, fair exchange has become an important concern between producers and retailers, especially for small scale producers due to their weak trading position in the world economies (Brown, 1993). Fair trade organizations provide alternate mechanism of trade which straightway links producers in developing countries with consumers in developed nations (Jaffe et.al, 2004). The main purpose of fair trade organizations 
(FTO) is to assist small scale producers and farmers in trading. It works for people development at the center and ensures payment of fair wages, improvement of working conditions and develop fair and dignified trade relationships while keeping workers sustainable.

Fair trade encourages responsible consumption and presents shoppers with socially and environmentally friendly products (Raynolds, 2012). Numerous studies have confirmed consumers concern for environmental and social issues. Along with environmental and social concern, ethical consumption has also been central to consumers concern in developed countries (Elliot \& Freeman, 2001) which has resulted to the growth of ethical products significantly in last two decades (Carrigan \& de Pelsmacker, 2009). Consumers are willing to spend extra amount of money for products certified as made in ethical ways (Elliott \& Freeman, 2003).

The consumers' need for social responsibility can be satisfied by private standards through improvement in employment and environmental conditions for production. The fair trade products have grown significantly by $30 \%$ annually over the years (Fairtrade Labelling Organization, 2012). Major global brands make use of these private standards to minimize risk and costs related to transactions and distinguish themselves from competitors. These standards equip consumers with information about product's technical details, their compliance on health and safety, environmental and labor conditions etc. under which products have been manufactured (Nadvi, 2008). The growth of fair trade products in specific categories such as ground coffee segment in EU $(2 \%)$, the banana segment in Switzerland (15\%), the roast coffee segment in UK $(7.2 \%)$ and the tea market in Germany $(2.5 \%)$ indicate the consumer preference for these products (Moore, 2004; Cafe direct plc, 2003). Since perception of fair trade affects consumers' consumption, therefore, in the light of above literature we theorize it as an important antecedent of responsible consumption and propose hypothesis.

H1: Perception of fair trade among consumers lead to responsible consumption.

\subsection{Environmental Education and Responsible Consumption}

Education on sustainable consumption aims at changing values and equipping people with knowledge, skills and practices that works for wellbeing of individuals and society within ecological boundary. The current lifestyle is being witnessed as posing new challenges to the sustainability and thus, endangering society over the years. Lack of environmental knowledge is big hindrance for consumers' behavior towards ecologically conscious decisions. With greater environmental knowledge, there are high chances of consumers indulging in ecological conscious behavior (Thøgersen, 2000). Consumers are happy to pay extra money for products having environmental and social attributes (de Pelsmacker et al., 2005). Environment protection was found to be an important determinant of consumption in china (MasterCard Worldwide Insights, 2007). Education focusing on meeting individual and societal needs in less consumptive way is imperative for environmental sustainability.

The solution to excess consumption lies in educating people about living with less and educating them about green knowledge 
Table 1. Identification of Variables

\begin{tabular}{|c|c|c|}
\hline Construct & Identification of variables & References \\
\hline \multirow{8}{*}{$\begin{array}{l}\text { Perception of } \\
\text { fair Trade }\end{array}$} & Environmental and safe working conditions compliance. & Reynold (2012) \\
\hline & & Fair Trade Federation (2002) \\
\hline & Fair wages and dignified life to workers. & Suchomel (2005) \\
\hline & & Murray et al. (2006) \\
\hline & & Elliott \& Freeman (2003) \\
\hline & Preference for fair trade certified products. & De Pelsmacker et al. (2005) \\
\hline & & Fairtrade Foundation (2006) \\
\hline & $\begin{array}{l}\text { Fair Trade Impact on Environmental and ethical } \\
\text { consumption. }\end{array}$ & Reynold (2012) \\
\hline \multirow{7}{*}{$\begin{array}{l}\text { Environmental } \\
\text { Education }\end{array}$} & & Henion (1972) \\
\hline & High environmental knowledge and environmental \& & Schahn \& Holzer (1990) \\
\hline & sustainable consumption & Tanner \& Kast (2003) \\
\hline & & Roubanis (2008) \\
\hline & $\begin{array}{l}\text { Improvement in consumption practices and } \\
\text { environmental awareness. }\end{array}$ & Thøgersen, (2000) \\
\hline & Education and consumers responsibility & Fisk (1973) \\
\hline & $\begin{array}{l}\text { Development of environmental curriculum and } \\
\text { improvement in consumption practices. }\end{array}$ & Kopnina (2011) \\
\hline \multirow{3}{*}{ Neuroticism } & Concern for Environment & Hirsh (2010) \\
\hline & $\begin{array}{l}\text { Uneasiness due behavior that is not environmental } \\
\text { friendly. }\end{array}$ & Hirsh (2010) \\
\hline & Discourage unnecessary consumption & $\begin{array}{l}\text { Promoting Sustainable } \\
\text { Consumption, (2008) }\end{array}$ \\
\hline \multirow{3}{*}{ Taxation } & Expensive & \\
\hline & High taxes on unsustainable and un-environmental & Fisk (1973) \\
\hline & friendly products. & Rabasso \& Rabasso (2011) \\
\hline $\begin{array}{l}\text { Responsible } \\
\text { Consumption } \\
\end{array}$ & Rational and efficient use of resources & Fisk (1973) \\
\hline
\end{tabular}

(Rabasso \& Rabasso, 2011). The educational institutions in particular need to develop and impart education which includes general awareness on consumption, social responsibility with respect to consumption, environmental awareness on energy and water usage, recycling and long term consequences of overconsumption (Kopnina, 2011). Schools and parents should contribute by educating children about responsible consumption. They must take initiatives to imbibe values that promote responsible behvaiour among children at early stage. The awareness on responsible consumption can be enhanced by increasing courses related to green responsibility and green management by B schools (McDonagh \& Prothero, 1997).
Since ecological concern and sustainable consumption are central to the responsible consumption, therefore, we deduce environmental education as an important antecedent of responsible consumption and propose hypothesis.

H2: Environmental education among consumers lead to responsible consumption.

\subsection{Neuroticism as Personality Trait and Responsible Consumption}

Personality is defined as a pattern of behavior and set of characteristics that determines people adaptation to the environment (Richard, 1993). Personality 
has been explained in term of big five traits namely: openness to experience, conscientiousness, extraversion, agreeableness and neuroticism (emotional stability) by Goldberg (1990). Consumers' personality plays an important role in decision making process and influence the way consumers make purchase. Neuroticism is individual's tendency to experience psychological distress (Costa \& McCrae, 1995). People who score high in neuroticism feel more depressed, anxious, apprehensive and angry (Major et al., 2006). Hirsh (2010) reported correlation between environmental concern and neuroticism. High neurotic individuals' show generally more concern about environment. People high on neuroticism tend to be emotionally labile and frequently complain of worry and anxiety. Neurotic individuals respond emotionally to all kinds of negative scenarios (e.g. increasing environmental degradation, pollution etc.in our case) and tries to minimize their occurrence (Hirsh, 2010).

Neurotic individuals are found to extend support for environmental preservation (Wiseman \& Bogner, 2003). Environmental concern is the essence of responsible consumption and sustainable and green products are good for the environment (Luchs et al., 2010). Consumption of green or sustainable products protect environment, minimize environmental degradation and reduce toxic waste and pollution (Ottman, 2008) so this consumption can be termed as responsible. High neurotic individuals' tend to feel distress and anxiety while indulging in consumption that is not sustainable, environmental friendly and harmful to environment (Hirsh, 2010). Considering environmental concern and sustainable consumption as core element of responsible consumption, it is inferred that personality trait i.e. neuroticism causes responsible consumption and is an important antecedent of it, therefore hypothesis is proposed.

H3: Consumers high on neuroticism are more likely to exhibit responsible consumption.

\subsection{Taxation and Responsible Consumption}

Private consumption has been the root cause of environmental problems most of the time. The cost of irresponsible consumption is very high and born by not only the one who is over consuming but by all of us. Change in consumption practices towards responsible consumption can offset negative climate and environmental impact of consumption. Therefore, strategy that makes it easier for consumers to act sustainably and responsibly must be contemplated to support change in consumption habits. Imposing tax over products that are not environmental friendly can be thought as one of such strategy. Taxation is economic instrument that can be used to address environmental problem and promote sustainable alternatives. Taxes have been very effective in motivating consumers' towards sustainable choices (Promoting Sustainable Consumption, 2008). Taxes discourage consumption of unsustainable choices by increasing prices. Imposition of taxes may help in limiting car emission (e.g. fuel taxes, purchase and registration taxes and congestion charges), household energy consumption (e.g. CO2 taxes, electricity taxes), water and household waste (waste disposal tax). There are many instances where imposition of taxes has been instrumental in improving consumption habits of consumers'. Countries like Finland, 
Austria, Germany and Sweden have introduced environmental taxes to promote sustainable consumption. Denmark successfully cut down the water consumption by increasing the water prices by $150 \%$ after implementing taxes (Promoting Sustainable Consumption, 2008). Another successful example is of Ireland. Ireland managed to control the use of plastic bag by $92 \%$ after levying 15 cent on plastic bag. This encouraged the shoppers to use reusable bags instead of plastic bags and the money generated out of this were used to support initiative such as waste management and environmental initiatives (Promoting Sustainable Consumption, 2008). The congestion charges were levied in London to manage bourgeoning congestion problem in the city and to encourage the use of public transport. This initiative has improved the congestion problem of city and traffic levels have come down by $10.2 \%$ in the past ten tears (Transport for London Report, 2008). Based on the above literature, it is deduced that taxation on unsustainable goods lead to changes in the consumption habits. Therefore, it is considered as an important antecedent of responsible consumption and the following hypothesis is proposed.

H4: Imposition of high taxes on unsustainable goods lead to responsible consumption.

\section{RESEARCH METHODOLOGY}

A survey was conducted to test the propounded hypotheses in Dehradun city. Dehradun being the capital Uttarakhand, is known for good schooling and is also the hub of higher education. The institute of national repute like Forest Reserve Institute, Indian Military Academy, Survey of India, Oil and Natural Gas Corporation and Indian Institute of Petroleum have their headquarter in Dehradun. Due to the presence of institutes of national repute and higher education, people are high on awareness about sustainability, environmental and consumption related issues. Simple random sampling was used to collect the data. Structured questionnaire was prepared to get respondents opinion towards antecedents of responsible consumption. Overall, the questionnaire yielded 300 responses out of 350. 50 questionnaires were removed from the analysis due to inadequate information and final analysis was done using only 300 questionnaires. Pilot testing has been conducted to validate the survey instruments and items were finalized after ensuring reliability of the survey.

\section{DATA ANALYSIS AND RESULTS}

\subsection{The instruments}

The questionnaire is categorized in two sections to address five hypotheses proposed in the study. The first section details respondents' demographic information such as age, gender, income and education. The second section captures four items each of environmental education, perception of fair trade, neuroticism, taxation and responsible consumption. To measure constructs, scales have been developed. All five constructs were measured using four items each. Some of the items incorporated in scales were developed using literature and some items have been included after consultation with academicians and domain experts. The scales were further tested for reliability and 
validity. Pilot study was conducted to ensure the reliability of the scales. Cronbach's alpha values for all scales were higher than recommended value 0.7 (Sekaran \& Bougie, 2003). Further, content validity has been ensured using experts opinion. Since scales used in study exhibit good reliability and validity, therefore, they are considered fit for further analysis. All items have been measured with the help of Likert scale where 1 indicates strongly disagree and 5 indicate for strongly agree.

\subsection{Sample Characteristics}

Table 2 shows the demographic profile of respondents. Total 300 respondents were surveyed. Out of 300 respondents, $56.7 \%$ were male and $43.3 \%$ were female. $46.7 \%$ respondents' fall in the age group of 35-45 followed by $30 \%$ in the age group of $25-35$. More than $50 \%$ respondents are having post graduate qualification. Income wise, majority of the respondents belong to 60000 80000 category whereas $26 \%$ belong to 40000-80000 category.

Table 2. Demographic profile of respondents

\begin{tabular}{llcc}
\hline Variable & Categories & Frequency & Response $(\boldsymbol{\%})$ \\
\hline \multirow{2}{*}{ Gender } & Male & 170 & 56.7 \\
& Female & 130 & 43.3 \\
Age & 25-35 years & 90 & 30.0 \\
& 35-45 Years & 140 & 46.7 \\
& 45-60 Years & 70 & 23.3 \\
Education & Graduate & 90 & 30.0 \\
& Post Graduate & 155 & 51.7 \\
& Others & 55 & 18.3 \\
& 20000-40000 & 60 & 20.0 \\
& $40000-60000$ & 80 & 26.7 \\
& $60000-80000$ & 90 & 30.0 \\
& 80000 Above & 70 & 23.3 \\
\hline
\end{tabular}

\subsection{SEM}

SEM is technique that makes use of multiple regressions in combination with confirmatory factor analysis to estimate simultaneously a series of interrelationship between the constructs of the proposed model. The SEM technique is composed of two components: the measurement model and structural model. The measurement model is used to test the reliability and validity of constructs apart from testing relationship between observed variable and latent variables (Doloi et al., 2011). The structural model tests the path strength and direction of the relationships among the latent variables.

The measurement model. The confirmatory factor analysis (CFA) was carried out to test the measurement model using AMOS. 18. The measurement model should have satisfactory level of validity and reliability. The test of reliability and validity is essential before the testing for interrelationship in the structural model (Fornell \& Larcker, 1981; Ifinedo, 2006). Figure 1 depicts the final measurement model for latent constructs that leads to responsible consumption. Constructs environmental education, perception of fair trade, neuroticism, taxation and responsible consumption are indicated by four items each. Total 20 items were used to measure five constructs.

The measurement model was subjected to test for psychometric properties in terms of reliability, convergent validity and discriminant validity. Internal consistency is calculated to confirm the reliability which is a measure of different survey items that intends to measure the same characteristics. The Cronbach's alpha is indicator of internal consistency. This statistics is computed from 
pairwise correlation between items which ranges from 0 to 1 . Table 3 shows the reliability of each constructs. The Cronbach's alpha value above 0.7 is considered to be good (Sekaran \& Bougie, 2003). Therefore, we can say that all constructs have good reliability as Cronbach's alpha score for each constructs is above 0.7. Therefore, these measures are deemed relevant for SEM analysis further.

The validity is established using convergent and discriminant validity in the measurement model. Convergent validity shows how much proportion of variance in indicators of specific constructs is common or converge (Hair et al., 2010). Standardized factor loadings are used to measure this validity. The standardized regression weights are significant and prove that the indicator variables are significant and representative of their latent constructs. Factor loadings should be above 0.5 for latent to observed variables (Hair et al., 2010). The factor loading of all observed variables in Table 3 show that they all range from 0.5 to 0.93 . This indicates the observed variables are good enough and belong to their constructs. So this confirms the convergent validity for construct.

Discriminant validity is measure of how constructs are distinct from each other (Hair et al., 2010). Two methods are commonly

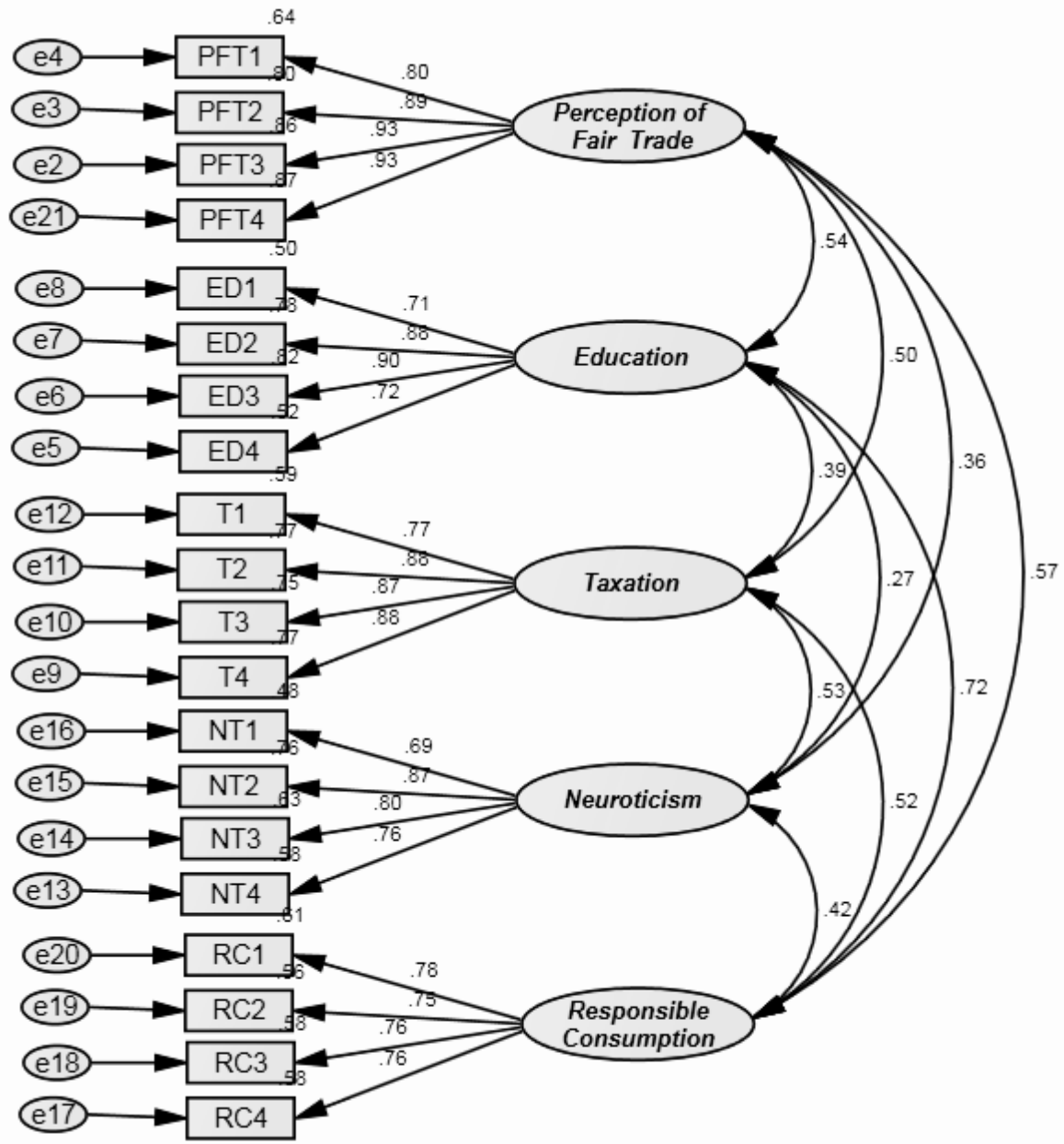

Figure 1: Measurement Model 
Table 3: Reliability and items loading

\begin{tabular}{|c|c|c|c|c|}
\hline Construct & Items & Description & $\begin{array}{c}\text { Standard } \\
\text { factor } \\
\text { loading }\end{array}$ & $\begin{array}{l}\text { Cronbach } \\
\text { Alpha }\end{array}$ \\
\hline \multirow{3}{*}{$\begin{array}{l}\text { Perception of } \\
\text { Fair trade }\end{array}$} & PFT1 & $\begin{array}{l}\text { Fair trade ensures compliance to environmental and safe } \\
\text { working conditions. }\end{array}$ & 0.80 & \multirow{3}{*}{0.93} \\
\hline & PFT2 & Fair trade ensures fair wages and dignified life to workers. & 0.89 & \\
\hline & PFT3 & Consumers prefer fair trade certified products. & 0.92 & \\
\hline \multirow{4}{*}{$\begin{array}{l}\text { Environmental } \\
\text { Education }\end{array}$} & PFT4 & $\begin{array}{l}\text { Fair trade certification or label promotes environmental } \\
\text { friendly products and ethical consumption. }\end{array}$ & 0.93 & \multirow{6}{*}{0.87} \\
\hline & E1 & $\begin{array}{l}\text { Consumers having environmental knowledge exhibit } \\
\text { environmental and sustainable consumption. }\end{array}$ & 0.70 & \\
\hline & E2 & $\begin{array}{l}\text { Environmental education equips consumers with skills and } \\
\text { values that helps them in deciding more responsible and } \\
\text { sustainable choices. }\end{array}$ & 0.88 & \\
\hline & E3 & $\begin{array}{l}\text { Awareness about environment helps in improving } \\
\text { consumption practices. }\end{array}$ & 0.90 & \\
\hline \multirow{5}{*}{ Neuroticism } & E4 & $\begin{array}{l}\text { Education curriculum must be resigned or updated to achieve } \\
\text { the goal of sustainable consumption. }\end{array}$ & 0.72 & \\
\hline & N1 & I am concerned about environment. & 0.70 & \\
\hline & $\mathrm{N} 2$ & I feel distressed when I don't use resources judiciously. & 0.87 & \multirow{3}{*}{0.85} \\
\hline & N3 & $\begin{array}{l}\text { I feel unease when I don't make ethical and sustainable } \\
\text { choices. }\end{array}$ & 0.79 & \\
\hline & N4 & $\begin{array}{l}\text { Buying environmental friendly goods makes me feel happy } \\
\text { and helps me reducing my anxiety. }\end{array}$ & 0.75 & \\
\hline \multirow{3}{*}{ Taxation } & $\mathrm{T} 1$ & High taxes on goods discourage unnecessary consumption. & 0.76 & \multirow{3}{*}{0.90} \\
\hline & $\mathrm{T} 2$ & $\begin{array}{l}\text { Taxation makes goods expensive, thereby limiting people } \\
\text { consumption. }\end{array}$ & 0.88 & \\
\hline & $\mathrm{T} 3$ & $\begin{array}{l}\text { High taxes must be imposed on goods that are not sustainable } \\
\text { and environmental friendly. }\end{array}$ & 0.86 & \\
\hline \multirow{5}{*}{$\begin{array}{l}\text { Responsible } \\
\text { Consumption }\end{array}$} & $\mathrm{T} 4$ & $\begin{array}{l}\text { High taxes on unsustainable products motivate consumers to } \\
\text { use goods rationally. }\end{array}$ & 0.87 & \multirow{5}{*}{0.87} \\
\hline & $\mathrm{RC} 1$ & I always make rational consumption. & 0.76 & \\
\hline & $\mathrm{RC} 2$ & I always prefer environmental friendly products. & 0.76 & \\
\hline & $\mathrm{RC} 3$ & I try to buy ethical and sustainable choices. & 0.75 & \\
\hline & $\mathrm{RC} 4$ & $\begin{array}{l}\text { Buying environmental friendly products in judicious manner } \\
\text { will improve environment and ensure longevity of scarce } \\
\text { resources. }\end{array}$ & 0.76 & \\
\hline
\end{tabular}

used to measure discriminant validity. First, the correlation between measures of different construct should not be high. It also means that instrument used to measure different construct should not have high correlation with other instrument that is intended to measure distinct characteristics (Trochim, 2006). Second average variance extracted of individual constructs are higher than the average shared variance between the constructs and the level of square root of AVE should be greater than the correlation involving the constructs. Table 4 exhibits that all construct have low correlation with each other. This indicates the independence of all constructs in the model. Apart from this, the average variance extracted of each constructs are higher than the shared variances between the constructs (Table 4). The square root of the AVE shown in bold (Table 4) are higher than the off-diagonal elements in the corresponding rows and columns and exceed than the correlation between the given construct. This proves that the constructs have higher correlation with its indicators than with the other constructs 
in the measurement model. So, it can be said that the model appears satisfactory at the construct level in case of all constructs.

The model fit were tested using fit indices like comparative fit indices (CFI), the goodness of fit index (GFI), normed fit index (NFI), tucker levis index (TLI) and root mean square error approximation (RMSEA) (Hair et al., 2010). For model to be fit, the recommended respective value of $\chi^{2}$ should be less than 3. The value of CFI, GFI, NFI and TLI should be more than 0.9 and RMSEA value must be less than 0.08 (Gefen et al., 2000). Table 5 presents the summary of goodness of fit indices for measurement model. The respective $\chi^{2} / \mathrm{df}, \mathrm{CFI}, \mathrm{GFI}, \mathrm{NFI}$ and TLI values are 2.326, 0.96, 0.91, 0.93 and 0.943 . The RMSEA shows a value of 0.058 . Table 5 fairly demonstrates that measurement model had good fit with the collected data so we can further proceed for structural model testing using SEM.

Structural Model: SEM was applied to test the hypothesized conceptual research model. Table 6 depicts the goodness of fit for

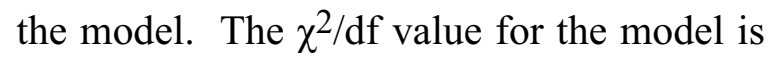

2.426. The other goodness of fit measures like CFI, GFI, NFI, TLI and RMSEA are $0.970,0.930,0.943,0.953$ and 0.059 respectively. Since all the values of goodness of it indices meet recommended criteria, the model is considered deemed fit for further analysis. Structural model has been shown in Figure 2.

The properties of structural model such as beta (standardized path coefficient), standard error, critical ratio and result of hypotheses are shown in Table 7. The significance level is set at 0.05. Squared multiple correlation $\mathrm{R} 2$ is reported at Table 7 . The $\mathrm{R}^{2}$ value in proposed model is the testimony of strength of model. The $\mathrm{R}^{2}$ value of the model shows that four exogenous constructs explain $62 \%$ of the variation in responsible consumption.

Table 7 presents the result of hypotheses testing where beta coefficients signify relative importance of each antecedents of responsible consumption. All expected relationships are found to be positive. The all four antecedents of responsible consumption are significant with different beta coefficients, thereby contributing different

Table 4. Correlation Matrix and roots of Average variance Extracted

\begin{tabular}{lccccccccc}
\hline & CR & AVE & MSV & ASV & NT & PFT & EE & TA & RC \\
\hline Neuroticism & 0.883 & 0.655 & 0.517 & 0.257 & $\mathbf{0 . 8 1}$ & & & & \\
Perception & 0.862 & 0.611 & 0.282 & 0.164 & 0.267 & $\mathbf{0 . 7 8 2}$ & & & \\
Education & 0.912 & 0.721 & 0.282 & 0.238 & 0.388 & 0.531 & $\mathbf{0 . 8 4 9}$ & & \\
Taxation & 0.938 & 0.79 & 0.328 & 0.248 & 0.538 & 0.359 & 0.495 & $\mathbf{0 . 8 8 9}$ & \\
Responsible & 0.848 & 0.583 & 0.517 & 0.323 & 0.719 & 0.417 & 0.523 & 0.573 & $\mathbf{0 . 7 6 3}$ \\
Consumption & & & & & & & &
\end{tabular}

Note: The diagonal values in italics represents square root of average variance extracted from observed variables: values other than diagonal values represents correlation between constructs.

Table 5: Summary of goodness of fit indices for measurement model

\begin{tabular}{ccccccc}
\hline Model fit Indices & $\boldsymbol{\chi} \mathbf{2} / \mathbf{d f}$ & CFI & GFI & NFI & TLI & RMSEA \\
\hline Model & 2.326 & 0.960 & 0.910 & 0.933 & 0.943 & 0.058 \\
\hline
\end{tabular}

Table 6: Summary of goodness of fit indices for structural model

\begin{tabular}{ccccccc}
\hline Model fit Indices & $\boldsymbol{\chi 2} / \mathbf{d f}$ & CFI & GFI & NFI & TLI & RMSEA \\
\hline Model & 2.426 & 0.970 & 0.930 & 0.943 & 0.953 & 0.059 \\
\hline
\end{tabular}


Table 7: Summary of testing of hypothesis

\begin{tabular}{|c|c|c|c|c|c|c|c|c|c|}
\hline & & & $\begin{array}{c}\text { Estimates } \\
(\boldsymbol{\beta})\end{array}$ & $\begin{array}{c}\text { Unstandardized } \\
\text { Regression } \\
\text { weight }\end{array}$ & S.E & CR & $\mathbf{P}$ & $\begin{array}{c}\text { Squared } \\
\text { Multiple } \\
\text { correlation } \\
\end{array}$ & Results \\
\hline $\begin{array}{l}\text { Responsible } \\
\text { Consumption }\end{array}$ & $<---$ & $\begin{array}{l}\text { Perception of } \\
\text { Fair Trade }\end{array}$ & 0.15 & 0.121 & 0.043 & 2.816 & 0.005 & \multirow{4}{*}{0.62} & Supported \\
\hline $\begin{array}{l}\text { Responsible } \\
\text { Consumption }\end{array}$ & $<---$ & Education & 0.53 & 0.49 & 0.056 & 8.749 & $* * *$ & & Supported \\
\hline $\begin{array}{l}\text { Responsible } \\
\text { Consumption }\end{array}$ & $<---$ & Taxation & 0.17 & 0.118 & 0.039 & 3.023 & 0.003 & & Supported \\
\hline $\begin{array}{l}\text { Responsible } \\
\text { Consumption }\end{array}$ & $<--$ & Neuroticism & 0.13 & 0.093 & 0.038 & 2.42 & 0.016 & & Supported \\
\hline
\end{tabular}

weights to variance of responsible consumption.

The most significant antecedent of responsible consumption is environmental education $(\beta=0.53: p<0.05)$. Hence $\mathrm{H} 2$, which states that environmental education leads to responsible consumption, is supported. The second important antecedent of responsible consumption is taxation $(\beta=0.17: p<0.05)$. So H4, which states that high taxation on unsustainable goods lead to responsible consumption, also stands supported. The third and fourth antecedents of responsible consumption are perception of fair trade $(\beta=0.15: p<0.05)$ and neuroticism $(\beta=0.13: p<0.05)$ respectively. Therefore, hypotheses $\mathrm{H} 1$ and $\mathrm{H} 3$ both are supported.

\subsection{Common Method Bias}

Common method bias refers to the most common bias found in survey. The common method bias has been tested using common latent construct method and is shown in Figure 3. According to this method, the absence of biasness is indicated when square of unstandardized regression weight is less than $30 \%$ in the model. The square of unstandardized regression weight here is $18 \%$.i.e. less than recommended threshold value $50 \%$ indicating the absence of biasness (Eichhorn, 2014).

\section{RESULTS AND DISCUSSIONS}

The deteriorating environment and fast depletion of resources have nowadays become the cause of concern for social activist and environmentalist. The rate at which resources are being consumed poses the challenge for survival of future. The insatiable lifestyle and disposable society has also contributed to resources depletion. This has mandated the need for more judicious use of resources and responsible consumption. In this study, we have a model where four construct were taken as antecedents of responsible consumption. Further, the relationships between antecedents of responsible consumption were tested in the model. The empirical evidences support the model and hypotheses proposed in the initial part of study. All four antecedents of responsible consumption i.e. perception of fair trade, education, taxation and neuroticism were found to have significant relationship with responsible consumption in the study.

The most important antecedent of responsible consumption is education $(\beta=0.53, p<0.001)$. This finding is in accordance to previous finding (Dé Rebello, 2003) which corroborate the importance of education in creating awareness and informing consumers' towards responsible consumption practices. Most of the 
unsustainable choices are the outcome of insufficient environmental knowledge. Educating consumers about responsible consumption choices and their responsibility as a consumers towards environment are important to change their behavior. The change in consumers' behavior requires collective efforts on the part of NGOs, local organization and government (GonzalezGaudiano, 2004). Companies too need to educate consumers about consuming things responsibly. The consumers must be encouraged to make only informed and well thought choices. The education about use of green and sustainable products should be disseminated by companies in order to conserve scare resources. The change in existing curriculum and syllabus must be done on priority so that students can be equipped to make better choices with respect to consumption (Rabasso \& Rabasso, 2011).
Education must aim to enable students to make better decisions and better uses of resources now and in future (Promoting Sustainable Consumption, 2008). Consumers should be taught and encouraged to collectively use the resources. Collective use of resources will minimize consumption of those resources that are used to make products that are not frequently used by people and consume good amount of resources (Fisk, 1973). Resources sharing can lead to conservation of most precious scarce resources. Apart from this, awareness about product made of recycled products and its benefits to consumers will be boon for the environment.

The second important antecedent of responsible consumption is taxation $(\beta=0.17$, $\mathrm{p}<0.5$ ). Taxes are used to change or regulate the consumers' behavior. Some countries have regulated the consumption by imposing

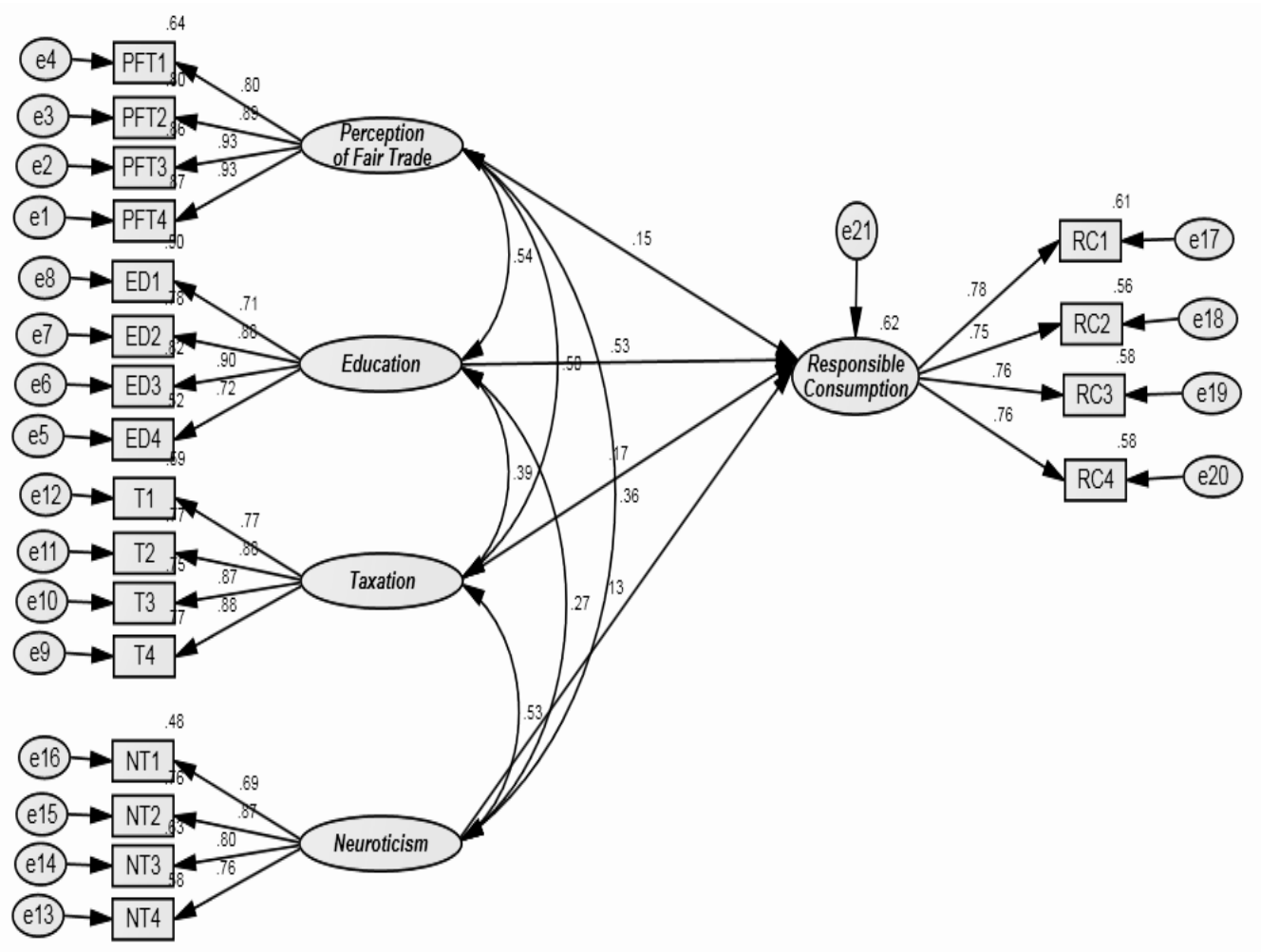

Figure 2: Structural Model 


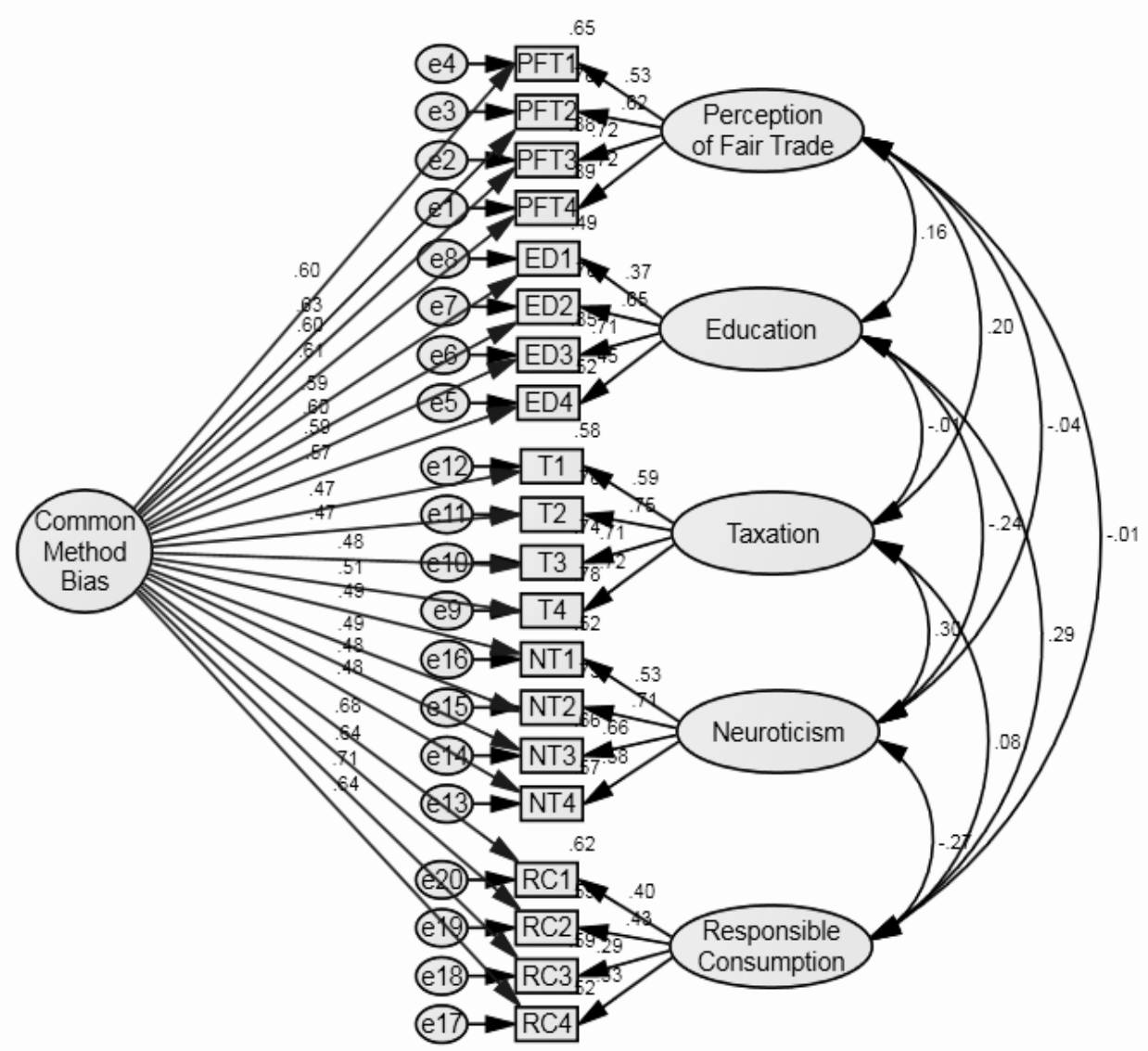

Figure 3: Latent Construct (Common Method Bias)

taxes on unsustainable goods. High taxes on less sustainable goods can prove to be significant in influencing consumer behavior (Promoting Sustainable Consumption, 2008). Imposition of high taxes on goods like inefficient vehicles, polluting products, plastic bags, and energy inefficient products can be effective to reduce the demand of these goods, thereby, improving environment and saving of resources. Government must plan new tax policy to promote green and sustainable consumption. New taxes like congestion charges and environmental taxes must be imposed in order to minimize the environmental damage. Reduction in taxes on goods made using recycled products and sustainable goods will enhance demand for these goods. Recycling will improve the usage of old resources and cut down the consumption of new resources, thereby conserving huge resources. Development of market for recycled goods can prove to be boon for country like India where demand of goods is huge due to population. Further, taxes must be cut down on repairing and maintenance of goods in order to enhance products life and its reusability.

Perception of fair trade is the third important antecedent of responsible consumption $(\beta=0.15, \mathrm{p}<0.5)$. This finding is in accordance to previous finding which state that fair trade encourage consumers' desire for responsible consumption and offers shoppers socially and environmentally 
friendly products (Raynolds, 2012). direction of research among future Consumers care about environment and researchers. They may like to delve into expects ethical behavior from companies. They are willing to pay for products that are made ethically and are certified by fair trade organizations (Elliott \& Freeman, 2003). With growing awareness, consumers now look for products that are made ensuring all regulatory compliances. Fair trade label fulfills consumers demand by ensuring labour, community and environmental compliance. The awareness about fair trade instill a sense of confidence among consumers that all ethical and environmental compliance have been taken care of in production of goods. Therefore, companies need to inform consumers about fair trade certification and labels in order to encourage ethical and environmental friendly consumption. In addition to companies, NGOs, civil societies and fair trade organizations must create awareness about fair trade products to sensitize consumers about better consumption choices.

The consumption choices of consumers are also affected by personality traits. In our study, neuroticism is found to affect responsible consumption $(\beta=0.13, p<0.5)$. This finding is supported by the previous finding which confirms positive relation between neuroticism and pro-environmental behavior and environmental preservation (Boeve de Pauw \& Van Petegem, 2011; Milfont \& Sibley, 2012). Neurotic individuals are more concerned about negative outcome like environmental degradation (Hirsh, 2010). Obviously, it follows that environment-harming consumption choices in a way should cause anxiety to them and therefore, propel neurotic people to engage in responsible consumption choices. This implicit indication is one of its kind and throws a new various paths from neuroticism to responsible consumption under different settings. However, the study indicates that selection of wrong consumption choices should create anxiety to highly neurotic people, yet it cannot be said conclusively. To do so, further research should test the finding using causal research.

\section{CONCLUSION AND LIMITATIONS}

The responsible consumption is relatively new domain of research and therefore, very few studies have been done so far in this area. This, being the first study, has tried to identify antecedents of responsible consumption. This research makes significant contribution in literature by identifying antecedents of responsible consumption. It further establish the relationships between responsible consumption and its antecedents. The findings of study will be useful in promoting and encouraging responsible consumption which will reduce the resources wastage. It will be help in curtailing unnecessary consumption and guide us towards more resources sharing economy. The study will be helpful in bridging consumption disparity that exist across world as larger portion of world population still has very less at disposal to meet their basic needs. The findings will contribute towards sustainable development and poverty alleviation goals by promoting fair trade certified products. Despite its significant contribution, the present study is not free of limitations. Literature inadequacy was the main limitation as very few studies have been conducted in this domain. 


\section{DIRECTION FOR RESEARCH}

In this study, we have only identified four antecedents of responsible consumption but more antecedents could be identified in future. Further, they need to be statistically validated using structural equation modeling. Second, the antecedents of responsible consumption may vary across countries due to socio economic differences so this requires further examination.

\section{References}

Boeve de Pauw, J., \& Van Petegem, P. (2011). The effect of Flemish eco schools on student environmental knowledge, attitudes and affect. International Journal of Science Education, 33 (11), 1513-1538.

Brown, M.B. (1993). Fair trade: Reform and realities in the international trading system. Zed Books. London.

Cafe direct plc. (2003). Cafe direct plc Report and Financial Statements 2001-2002. (Baker Tilly International, London).

Campbell, C. (1987). The romantic ethic and the spirit of modern consumerism. Oxford, UK: B. Blackwell.

Carrigan, M., \& de Pelsmacker, P. (2009). Will ethical consumers sustain their values in the global credit crunch? International Marketing Review, 26 (6), 674-687.

Costa, P.T., \& McCrae, R.R. (1995). Domains and Facets: Hierarchical personality assessment using the Revised NEO Personality Inventory. Journal of Personality Assessment, 64 (1), 21-50.

De Pelsmacker, P., L. Driesen., \& G, Rayp. (2005). Do consumers care about ethics? Willingness to pay for fair-trade coffee. Journal of Consumer Affairs, 39 (2),
363-385.

Dé Rebello, D. (2003). The Role for Higher Education Institutions in the UN Decade of Edu-cation for Sustainable Development. International Conference on Education for a Sus-tainable Future Shaping the Practical Role of Higher Education for a Sustainable Development, Charles University, Karolinum, Prague, Czech Republic.

Doloi, H., Iyer, K.C., \& Sawhney, A. (2011). Structural equation model for assessing impacts of contractor's performance on project success. International Journal of Project Management. 29 (6), 687-695.

Eichhorn, B.R. (2014). Common method variance techniques. Cleveland State University, Department of Operations \& Supply Chain Management. Cleveland, $\mathrm{OH}$ : SAS Institute Inc.

Elliott, K.A., \& Freeman, R.B. (2001). White hats or Don Quixotes? Human rights vigilantes in the global economy. National Bureau of Economic Research, Cambridge.

Elliott, K. A., \& Freeman, R.B. (2003). Can Labor Standards Improve Under Globalization?Institute for International Economics. Washington, DC.

Fair Trade Federation. (2002). Report on Fair Trade Trends in the US and Canada, Fair Trade Federation, Washington.

Fair Trade foundation (2006). Annual Report and Financial Statements. Retrieved $\begin{array}{lllll}\mathrm{f} & \mathrm{r} & \mathrm{o} & \mathrm{m}\end{array}$ https://www.fairtrade.org.uk/ /media/Fairtra deUK

Fairtrade Labelling Organization (FLO). International Annual Report (2012). Retrieved from http:/www.fairtrade.net/annual-reports.html

Fisk, G. (1973). Criteria for a theory of responsible consumption. Journal of 


\title{
ИСТРАЖИВАЊЕ ПРЕДУСЛОВА ОДГОВОРНЕ ПОТРОШЊЕ УПОТРЕБОМ МОДЕЛОВАЊА СТРУКТУРНИХ ЈЕДНАЧИНА
}

\author{
Vijay Kumar Jain, Pankaj Chamola
}

\section{Извод}

Вишегодишња употреба ресурса због прекомерне потрошње угрозила је животну средину и представља озбиљну бригу за све нас. Садашња стопа потрошње ресурса може лишити будућу генерацију ресурса у којима смо ми уживали. Очување ових ресурса на дуже захтева разумну и рационалну праксу потрошње од стране потрошача. Стога, одговорна потрошња је хитно неопходна како би се додатно сприечила деградација околине и исцрпљивање ресурса. Овај рад има за циљ да истражи основе одговорне потрошње. Развијен је теоријски модел да би се објаснили и емпиријски потврдили основе које су претходиле одговорној потрошњи. Као егзогене варијабле узета су четири претходника, а то су еколошко образовање, перцепција праведне трговине, опорезивање и емоционална стабилност. Модел је тестиран и статистички валидиран моделирањем структурних једначина ослањајући се на податке прикупљене од преко 300 испитаника. Едукација о животној средини се појавила као најважнији претходник одговорне потрошње, након чега следи опорезивање, перцепција праведне трговине и емоционална стабилност. Налаз студије доприноси повећању одговорног и разумног коришћења ресурса, чиме би се смањила потрошња и побољшало окружење.

Кључне речи: потрошља, праведна трговина, ресурси, одговорност

Marketing, 37 (2), 24-31.

Fornell, C., \& Larcker, D.F. (1981). Evaluating Structural Equation Models with Unobservable Variables and Measurement Error. Journal of Marketing Research, 18 (1), 39-50.

Gefen, D., Straub, D. W., \& Boudreau, M.C. (2000). Structural Equation Modeling and Regression: Guidelines for Research Practice. Communications of the Association for Information Systems, 4 (7), 1-70.

Goldberg, L.R. (1990). An alternative description of personality: The big five structure. Journal of Personality and Social Psychology, 59 (6), 1216-1229.

González-Gaudiano, E. (2004). Overview of the Situation of Education for Sustainable Development in Mexico. UNU-APEC Education Network Invitation Program for Education for Sustainable Development,
August 24-30, Yokohama, Japan.

Gonzalez, C., Korchia, M., Menuet, L \& Urbain, C. (2009). How do socially responsible consumers consider consumption? An Approach with the Free Associations Method. Recherche et Applications en Marketing, 24 (3), 25-41.

Hair, J.F., Black, W.C., Babin, B.J., \& Anderson, R.E. (2010). Multivariate Data Analysis. Seventh edition. Prentice Hall, Upper Saddle River, New Jersey.

Henion, K.E. (1972). The effect of ecologically Relevant Information on Detergent Sales. Journal of Marketing Research, 9, 10-14.

Hirsh, J.B. (2010). Personality and environmental concern. Journal of Environment Psychology, 30 (2), 245-248.

Human Development Report. (1998). Retrieved from https://hdr.undp.org/sites 
Ifinedo, P. (2006). Extending the Gable et al. Enterprise Systems Success measurement model: a preliminary study. Journal of Information Technology Management, 17 (1), $14-33$.

Jaffee, D. (2007). Brewing Justice: Fair Trade Coffee, Sustainability, and Survival. University of California Press, Berkeley.

Kopnina, H. (2011). What is responsible consumption? Discussing environment and consumption with children from different socioeconomic backgrounds in the Netherland. Environmentalist, 31, 216-226.

Luchs, M.G., Naylor, R.W., Irwin, J.R., \& Raghunathan, R. (2010). The sustainability liability: Potential negative effects of ethicality on product preference. Journal of Marketing, 74 (5), 18-31.

Major, D.A., Turner, J.E., \& Fletcher, T.D. (2006). Linking proactive personality and the big five to motivation to learn and development activity. Journal of Applied Psychology, 91 (4), 927-935.

MasterCard Worldwide Insights (2007). Dynamic drivers of China's consumer market - the middle class, modern women and DINKs (MasterCard and HSBC). Retrieved from http:/www.mastercard.com/us/company/en/ insights/pdfs/2007/ChinaConsumerDriversS.pdf

McDonagh, P., \& Prothero, A. (1997). Green Management: A Reader. The Dryden Press, HBJ, London.

Miles, S. (2000). Youth lifestyles in a changing world. McGraw-Hill Education (UK).

Milfont, T.L., \& Sibley, C.G. (2012). The big five personality traits and environmental engagement: Associations at the individual and societal level. Journal of Environmental Psychology, 32 (2), 187-195.

Moore, G. (2004). The fair trade movement: parameters, issues and future research. Journal of Business Ethics, 53 (1), 73-87.

Murray, D., Raynolds, L.T., \& Taylor, P.L. (2006). The future of Fair Trade coffee: dilemmas facing Latin America's small scale producers. Development in Practice, 16 (2), 179-191.

Nadvi, K. (2008). Global standards, global governance and the organization of global value chains. Journal of Economics Geography, 8 (3), 323-343.

Ottman, J.A. (2008). The five simple rules of green marketing. Design Management Review, 19 (4), 65-69.

Promoting Sustainable Consumption. Good practices in OECD countries. (2008). OECD Retrieved from https://www.oecd.org/greengrowth/4031737 3.pdf.

Rabasso, C., \& Rabasso, J. (2011). Chinese business students in France and" green" responsible consumption. International Journal of Innovation, Management and Technology, 2 (4), 326330.

Raynolds, L.T. (2012). Fair Trade: Social regulation in global food markets. Journal of Rural Studies, 28 (3), 276-287.

Roubanis, J.L. (2008). Comparison of environmentally responsible consumerism and voluntary simplicity lifestyle between US and Japanese female college students. Family and Consumer Sciences Research Journal, 37 (2), 210-218.

Schahn, J., \& Holzer, E. (1990). Studies of individual environmental concern the role of knowledge, gender, and background variables. Environment and Behavior, 22 (6), 767-786.

Sekaran, U., \& Bougie, R. (2003). Research methods for business: A skillbuilding approach. 4th Edition, John Wiley 
\& Sons, New York.

Suchomel, K. (2005). Student Knowledge

and Support for Fair Trade: An Opinion Poll

of College Students, Conducted by

Minnesota Public Interest Research Group.

Tanner, C. \& Kast, S.W. (2003).

Promoting sustainable consumption determinants of green purchases by Swiss consumers. Psychology and Marketing, 20 (1), 883-901.

Thøgersen. J (2000). Knowledge barriers to sustainable consumption. In: Bone, P.F., France, K.R., \& Wiener, J. (eds). Marketing and public policy conference proceedings. American Marketing Association. Chicago, 29-39.

Trochim, W.M., \& Donnelly, J.P. (2006). The Research Methods Knowledge Base. 3rd Edition, Atomic Dog, Cincinnati, $\mathrm{OH}$.

United Nations. (2016). Sustainable Development Goals Report 2016. UN. Retrieved from \https://www.un.org/development/.../sustaina ble-development-goals-report-2016.

Wagner, W. (1960). Responsible Consumption. Retrieved from: http://www.unescoetxea.org/ext/manual_ED S/pdf/15_consumo_ingles.pdf(12/12/2017)

Wiseman, M., \& Bogner, F.X. (2003). A higher-order model of ecological values and its relationship to personality. Personality and Individual differences, 34 (5), 783-794. 